\title{
Effect of Lead on the Transformation of Urea-N in Fly Ash-Contaminated Soils under Different Moisture Regimes
}

\author{
D.K. Das ${ }^{1, *}$, P. Bashetti ${ }^{1}$, S.K. Naik ${ }^{2}$, and Pintu Sur ${ }^{1}$ \\ ${ }^{1}$ Department of Agricultural Chemistry and Soil Science, Bidhan Chandra Krishi \\ Viswavidyalaya, Mohanpur-741252, Nadia, West Bengal, India; ${ }^{2}$ National Research \\ Centre for Orchids, Pakyong-737106, Sikkim, India \\ E-mail: dkdas1231@sify.com; pbashetti@rediffmail.com; sushantanaik7@gmail.com; \\ pintu soil@yahoo.co.in
}

Received July 28, 2006; Revised April 28, 2007; Accepted April 28, 2007; Published June 12, 2007

\begin{abstract}
Urea is applied to soil for plant growth and undergoes various changes while in the soil. The mobility of heavy metals changes with the transformation of urea applied to the soil that, in turn, affects the activity of microbial biomass. The objective of this study was to determine the interaction between lead $(\mathrm{Pb})$ and urea under two moisture regimes $(60 \%$ and saturated water contents). At $60 \%$ water content, the amount of $\mathrm{NH}_{4}-\mathrm{N}$ decreased with the incubation time, irrespective of $\mathrm{Pb}$ and urea applied, while the amount of $\mathrm{NO}_{3}-\mathrm{N}$ content in the soil gradually increased with the incubation period to 28 days, and such an increase was counteracted by application of $\mathrm{Pb}$. The amount of $\mathrm{NO}_{3}-\mathrm{N}$ content was higher than that of $\mathrm{NH}_{4}-\mathrm{N}$, however, under saturated moisture condition, the amount of $\mathrm{NH}_{4}-\mathrm{N}$ was increased with the incubation time regardless of the levels of $\mathrm{Pb}$ application. The amount of $\mathrm{NO}_{3}-\mathrm{N}$ content in the soil gradually decreased with the advance of incubation at saturated condition. Although application of urea increased the $\mathrm{NO}_{3}-\mathrm{N}$ content in the soil, such an increase was suppressed by the application of different levels of $\mathrm{Pb}$ at water saturated condition throughout the incubation period.
\end{abstract}

KEYWORDS: lead, moisture regime, $\mathrm{NH}_{4}-\mathrm{N}, \mathrm{NO}_{3}-\mathrm{N}$, urea- $\mathrm{N}$, transformation

\section{INTRODUCTION}

The soils of high traffic density areas and other industrial regions have been polluted from a wide range of sources with $\mathrm{Pb}, \mathrm{Cd}, \mathrm{Hg}$, As, and other heavy metals. With the expansion of industrialization in India, the problem of the disposal of industrial effluents, in both liquid and solid forms, has been drawing the attention of many soil scientists and environmentalists. These pollutants reach agricultural lands directly or indirectly[1]. Soderstrom et al.[2] reported that with decreased soil water potential, following mineral $\mathrm{N}$ application and declining $\mathrm{pH}$ resulting from nitrification of $\mathrm{NH}_{4}{ }^{+}$sources, the activity of microorganisms is reduced. However, application of fertilizer can directly stimulate the growth of microbial populations as a whole by applying nutrients and may affect the composition of individual microbial communities in soil[3,4]. 
The added heavy metals degrade the soil by modifying the ionic composition and biological activity. Urea, extensively used as a source of $\mathrm{N}$, is applied to the soil. Urea undergoes many changes before the $\mathrm{N}$ becomes available to the plants[5]. Pollutants, such as sewage-sludge and other industrial effluents, are disposed to the environment and contain heavy metals, including Pb. When urea is added to the soils contaminated with heavy metals, especially with $\mathrm{Pb}$, transformation of urea may influence the mobility of the heavy metals. The rate of urea hydrolysis was not a linear function of moisture content, but increased with field capacity, and the added urea was completely hydrolyzed within 3 days at 40, 80, and 100\% field capacity[6]. Antil et al.[7] suggested that the urea hydrolysis followed the first-order kinetics and the rate of hydrolysis reduced with an increase in the $\mathrm{Pb}$ content of the soil. The objective of the present investigation was to study the interaction between $\mathrm{Pb}$ and urea under two distinct moisture regimes $(60 \%$ and saturated water contents).

\section{EXPERIMENTAL METHODS}

The soil sample (0-15 cm depth) was collected from the Tribeni area of West Bengal, India, where the soil was contaminated mainly by fly ash. The soil sample was then air dried, powdered, and passed through an 80-mesh sieve. The physicochemical properties of the soil are given in Table 1 . The composition of the contaminated fly ash was analyzed separately and the total contents were Fe 600, Mn 450, $\mathrm{Cu} 48, \mathrm{Zn} \mathrm{210,} \mathrm{Ni} 148$, and $\mathrm{Pb} 18 \mathrm{mg} \mathrm{kg}^{-1}$. Ten grams of soil were taken in a series of incubation tubes. $\mathrm{Pb}$ at $0,10,20$, and $50 \mathrm{mg} \mathrm{kg}^{-1}$ prepared from lead chloride $\left(\mathrm{PbCl}_{2}\right)$ and $\mathrm{N}$ at $0,50,100$, and 200 $\mathrm{mg} \mathrm{kg} 1$ prepared from urea in the form of solution were added to the soil. The experiment was laid down in completely randomized design (CRD) with factorial concept. The 16 treatment combinations were replicated thrice. Analysis of variance (ANOVA) was carried out by CRD. The least significant difference (LSD) test was applied to evaluate the significance of the differences between the individual treatments.

TABLE 1

Physicochemical Properties of the Experimental Soil

\begin{tabular}{lc}
\hline Properties & Particulars \\
\hline $\mathrm{pH}$ & 6.48 \\
$\mathrm{EC}\left(\mathrm{dSm}^{-1}\right)$ & 0.26 \\
Organic C $\left(\mathrm{g} \mathrm{kg}^{-1}\right)$ & 14.8 \\
$\mathrm{CEC}\left[\mathrm{C} \mathrm{mol}\left(\mathrm{p}^{+}\right) \mathrm{kg}^{-1}\right]$ & 18.5 \\
Available $\mathrm{N}\left(\mathrm{kg} \mathrm{ha}^{-1}\right)$ & 464.0 \\
Available $\mathrm{P}\left(\mathrm{kg} \mathrm{ha}^{-1}\right)$ & 283.2 \\
Exchangeable K $\left(\mathrm{kg} \mathrm{ha}^{-1}\right)$ & 360.2 \\
DTPA extractable Pb $\left(\mathrm{mg} \mathrm{kg}^{-1}\right)$ & 7.6 \\
\hline
\end{tabular}

Two moisture regimes, i.e., one at $60 \%$ water holding capacity (WHC) of soil and the other at saturated condition, were maintained in all the samples throughout the incubation time by applying double distilled water every alternate day. All treatments were kept in the laboratory at a room temperature of about $30 \pm 1^{\circ} \mathrm{C}$. Then the soils were incubated for $0,7,14,21$, and 28 days under the two moisture regimes. At the end of the experiment, the soils were analyzed for the DTPA extractable Pb, following the method of Lindsay and Norvell[8], using an atomic absorption spectrophotometer (Perkin Elmer model A Analyst 100). The $\mathrm{NH}_{4}-\mathrm{N}$ and $\mathrm{NO}_{3}-\mathrm{N}$ contents were determined using the method described by Sahrawat and Burford[9]. 


\section{RESULTS AND DISCUSSION}

\section{Transformation of $\mathrm{NH}_{4}-\mathrm{N}$ at $60 \% \mathrm{WHC}$}

The results show that the amount of $\mathrm{NH}_{4}-\mathrm{N}$ content in the soil was significantly decreased with the progress of incubation, irrespective of $\mathrm{Pb}$ and urea added (Table 2). The magnitude of such a decrease varied with the treatments under $60 \%$ WHC. The $\mathrm{NH}_{4}-\mathrm{N}$ content in the soil recorded highest at 7 days after incubation and thereafter gradually decreased to 28 days at all levels of $\mathrm{Pb}$ and urea applied. The magnitude of the decrease was highest at 28 days after incubation. The amount of $\mathrm{NH}_{4}-\mathrm{N}$ content significantly increased over control following urea application and such an increase was counteracted by the application of different levels of $\mathrm{Pb}$. Gupta and Chaudhry[10] observed that low temperature along with $\mathrm{Pb}$ delayed the hydrolysis of urea significantly and the $\mathrm{NH}_{4}-\mathrm{N}$ persisted for a longer period in the soil. The magnitude of decrease in $\mathrm{NH}_{4}-\mathrm{N}$ content was highest with higher levels of $\mathrm{Pb}$ and urea applications. Nitant[11] reported that the amount of $\mathrm{NH}_{4}-\mathrm{N}$ content increased with increasing levels of urea while that of the same content decreased with the application of $\mathrm{Pb}$. The $\mathrm{NH}_{4}-\mathrm{N}$ content decreased with the progress of incubation and the maximum decrease was recorded in $\mathrm{Pb}_{20} \mathrm{~N}_{0}$ and $\mathrm{Pb}_{50} \mathrm{~N}_{0}$ treatment combinations throughout the incubation period.

TABLE 2

\section{Effect of Different Levels of $\mathrm{Pb}$ and $\mathrm{N}$ on the Changes in $\mathrm{NH}_{4}-\mathrm{N}\left(\mathrm{mg} \mathrm{kg}^{-1}\right)$ Content in Soil under} $60 \%$ WHC

\begin{tabular}{|c|c|c|c|c|c|c|c|c|c|c|c|c|c|c|c|c|}
\hline \multirow{3}{*}{$\begin{array}{l}\text { Treat- } \\
\text { ments }\end{array}$} & \multicolumn{16}{|c|}{ Period of Incubation (Days) } \\
\hline & \multicolumn{4}{|c|}{7} & \multicolumn{4}{|c|}{14} & \multicolumn{4}{|c|}{21} & \multicolumn{4}{|c|}{28} \\
\hline & $\mathbf{N}_{0}$ & $\mathrm{~N}_{50}$ & $\mathbf{N}_{100}$ & $\mathbf{N}_{200}$ & $\mathbf{N}_{0}$ & $\mathrm{~N}_{50}$ & $\mathbf{N}_{100}$ & $\mathbf{N}_{200}$ & $\mathrm{~N}_{0}$ & $\mathbf{N}_{50}$ & $\mathbf{N}_{100}$ & $\mathbf{N}_{200}$ & $\mathbf{N}_{0}$ & $\mathbf{N}_{50}$ & $\mathbf{N}_{100}$ & $\mathbf{N}_{200}$ \\
\hline $\mathrm{Pb}_{0}$ & 26.4 & 40.3 & 50.7 & 78.9 & 23.4 & 36.7 & 43.7 & 61.2 & 17.2 & 22.4 & 25.8 & 41.9 & 12.0 & 15.6 & 14.9 & 27.8 \\
\hline $\mathrm{Pb}_{10}$ & 24.9 & 38.4 & 53.6 & 76.5 & 23.4 & 29.8 & 41.9 & 60.2 & 17.1 & 21.6 & 27.8 & 50.8 & 12.1 & 15.5 & 13.7 & 37.6 \\
\hline $\mathrm{Pb}_{20}$ & 21.6 & 40.8 & 50.0 & 70.9 & 23.2 & 28.6 & 33.7 & 49.8 & 17.0 & 20.9 & 24.9 & 37.6 & 11.8 & 16.3 & 14.2 & 29.6 \\
\hline $\mathrm{Pb}_{50}$ & 23.1 & 45.6 & 52.0 & 69.4 & 22.8 & 32.6 & 35.7 & 50.6 & 16.8 & 23.7 & 26.2 & 38.0 & 11.9 & 15.9 & 18.8 & 23.2 \\
\hline \multicolumn{17}{|l|}{$\begin{array}{c}\operatorname{LSD}(p= \\
0.05)\end{array}$} \\
\hline $\mathrm{Pb}$ & & & 1.89 & & & & 2.15 & & & & 1.77 & & & & 1.70 & \\
\hline
\end{tabular}

The highest percent decrease (18.1\%) of $\mathrm{NH}_{4}-\mathrm{N}$ content was recorded in $\mathrm{Pb}_{20} \mathrm{~N}_{0}$ treatment combination, suggesting a suppressive effect of $\mathrm{Pb}$ on the $\mathrm{NH}_{4}-\mathrm{N}$ content in the soil resulting through the very little production of $\mathrm{NH}_{4}-\mathrm{N}$ from the urea hydrolysis. However, such a decrease in $\mathrm{NH}_{4}-\mathrm{N}$ was due to the slower rate of ammonification throughout the incubation period as affected by the application of various levels of $\mathrm{Pb}[12]$.

Fig. 1 shows the mean effect of $\mathrm{Pb}$ on the $\mathrm{NH}_{4}-\mathrm{N}$ content in the soil under $60 \%$ WHC. The $\mathrm{NH}_{4}-\mathrm{N}$ content gradually decreased with increased application of $\mathrm{Pb}$ up to 14 days of incubation and thereafter showed inconsistent decrease. It was observed that the highest decrease in $\mathrm{NH}_{4}-\mathrm{N}$ content was found when $\mathrm{Pb}$ was applied at $20 \mathrm{mg} \mathrm{kg}^{-1}$ throughout the incubation period. The percent decrease in $\mathrm{NH}_{4}-\mathrm{N}$ content from 7 to 28 days of incubation was 64.2, 59.2, 57.04, and $63.23 \%$ at $0,10,20$, and $50 \mathrm{mg} \mathrm{kg}^{-1}$ $\mathrm{Pb}$, respectively. The mean effect of urea application on the changes in $\mathrm{NH}_{4}-\mathrm{N}$ content in the soil under $60 \%$ WHC is given in Fig. 2. The $\mathrm{NH}_{4}-\mathrm{N}$ content increased significantly with higher levels of $\mathrm{N}$ and gradually decreased with the progress of the incubation period. The percent decrease from 7 to 28 days after incubation was 50.2, 61.7, 70.13, and $60 \%$ at $0,50,100$, and $200 \mathrm{mg} \mathrm{kg}^{-1} \mathrm{~N}$, respectively. 


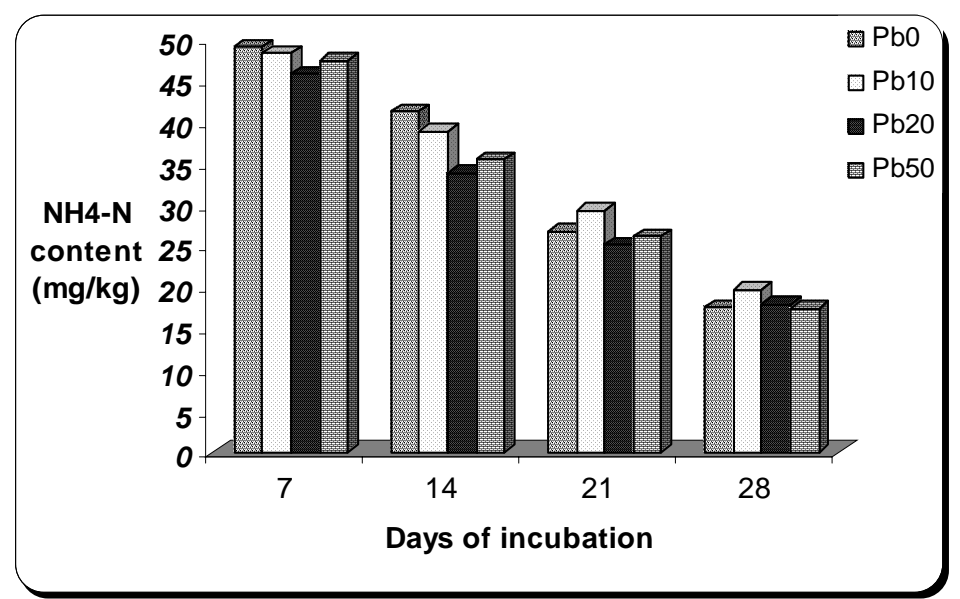

FIGURE 1. Mean effect of different levels of $\mathrm{Pb}$ on the changes in $\mathrm{NH}_{4}-\mathrm{N}$ content in soil under $60 \%$ WHC.

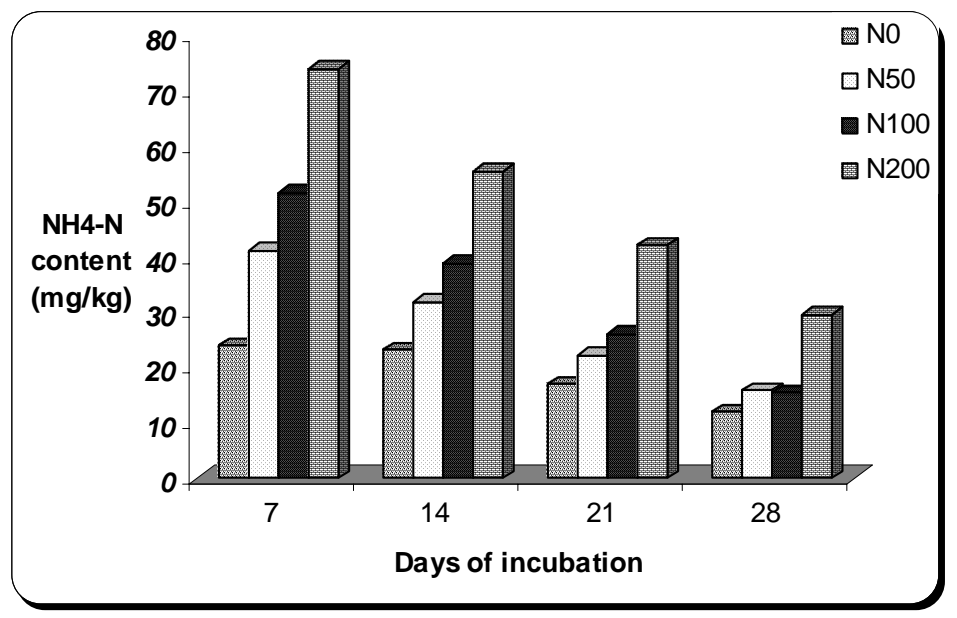

FIGURE 2. Mean effect of different levels of $\mathrm{N}$ on the changes in $\mathrm{NH}_{4}-\mathrm{N}$ content in soil under $60 \%$ WHC.

\section{Transformation of $\mathrm{NO}_{3}-\mathrm{N}$ at $60 \% \mathrm{WHC}$}

The amount of $\mathrm{NO}_{3}-\mathrm{N}$ content in the soil at $60 \%$ WHC was gradually increased with the progress of the incubation period of 28 days, irrespective of $\mathrm{Pb}$ and urea applied (Table 3). The magnitude of increase, however, was found to be significantly changed with the treatments. The highest amount of $\mathrm{NO}_{3}-\mathrm{N}$ content of $140.8 \mathrm{mg} \mathrm{kg}^{-1}$ was recorded in the treatment $\mathrm{Pb}_{0} \mathrm{~N}_{200}$ (where 0 and $200 \mathrm{mg} \mathrm{kg}^{-1}$ of $\mathrm{Pb}$ and $\mathrm{N}$ was applied), showing 306.9\% increase over control $\left(\mathrm{Pb}_{0} \mathrm{~N}_{0}\right)$. Antil et al.[7] also observed that the amount of $\mathrm{NO}_{3}-\mathrm{N}$ content enhanced with the incubation period and the maximum nitrification was observed between 7 and 14 days of incubation.

Increasing the levels of $\mathrm{Pb}\left(10-50 \mathrm{mg} \mathrm{kg}^{-1}\right)$ significantly decreased the $\mathrm{NO}_{3}-\mathrm{N}$ content throughout the period of incubation, while increasing the levels of $\mathrm{N}$ (50 to $200 \mathrm{mg} \mathrm{kg}^{-1}$ ) significantly increased the $\mathrm{NO}_{3}$ $\mathrm{N}$ content. This is also supported by Gupta and Chaudhry[13]. Such an inhibitory effect of different levels of $\mathrm{Pb}$ may be due to the toxicity to the activity of nitrifiers[14,15]. The amounts of $\mathrm{NO}_{3}-\mathrm{N}$ were found significant among the different treatments when $\mathrm{Pb}$ and $\mathrm{N}$ were applied at their higher level while the same was at par with different levels of $\mathrm{Pb}$ when no $\mathrm{N}$ was added. 
TABLE 3

Effect of Different Levels of $\mathrm{Pb}$ and $\mathrm{N}$ on the Changes in in $\mathrm{NO}_{3}-\mathrm{N}\left(\mathrm{mg} \mathrm{kg}^{-1}\right)$ Content in Soil under $60 \%$ WHC

\begin{tabular}{|c|c|c|c|c|c|c|c|c|c|c|c|c|c|c|c|c|}
\hline \multirow{3}{*}{$\begin{array}{l}\text { Treat- } \\
\text { ments }\end{array}$} & \multicolumn{16}{|c|}{ Period of Incubation (Days) } \\
\hline & \multicolumn{4}{|c|}{7} & \multicolumn{4}{|c|}{14} & \multicolumn{4}{|c|}{21} & \multicolumn{4}{|c|}{28} \\
\hline & $\mathrm{N}_{0}$ & $\mathrm{~N}_{50}$ & $\mathbf{N}_{100}$ & $\mathbf{N}_{200}$ & $\mathbf{N}_{0}$ & $\mathrm{~N}_{50}$ & $\mathbf{N}_{100}$ & $\mathbf{N}_{200}$ & $\mathbf{N}_{0}$ & $\mathbf{N}_{50}$ & $\mathbf{N}_{100}$ & $\mathbf{N}_{200}$ & $\mathrm{~N}_{0}$ & $\mathrm{~N}_{50}$ & $\mathbf{N}_{100}$ & $\mathbf{N}_{200}$ \\
\hline $\mathrm{Pb}_{0}$ & 34.6 & 50.6 & 60.9 & 98.7 & 42.5 & 59.1 & 72.6 & 116.8 & 44.6 & 75.9 & 93.7 & 130.0 & 49.8 & 83.6 & 99.6 & 140.8 \\
\hline $\mathrm{Pb}_{10}$ & 34.0 & 46.2 & 63.9 & 90.2 & 41.8 & 59.0 & 78.4 & 100.6 & 43.5 & 69.6 & 94.6 & 108.4 & 49.5 & 76.2 & 104.5 & 117.0 \\
\hline $\mathrm{Pb}_{20}$ & 34.2 & 49.8 & 59.9 & 83.6 & 42.0 & 61.8 & 68.7 & 90.7 & 44.0 & 79.4 & 92.8 & 108.4 & 48.6 & 85.4 & 103.4 & 121.6 \\
\hline $\mathrm{Pb}_{50}$ & 33.5 & 56.1 & 63.1 & 79.6 & 41.3 & 69.4 & 76.9 & 91.8 & 43.7 & 84.0 & 89.8 & 100.6 & 48.2 & 94.0 & 98.3 & 111.2 \\
\hline \multicolumn{17}{|l|}{$\begin{array}{l}\operatorname{LSD}(p= \\
0.05)\end{array}$} \\
\hline $\mathrm{Pb}$ & & & 1.34 & & & & 1.77 & & & & 2.99 & & & & 1.73 & \\
\hline $\mathrm{N}$ & & & 1.34 & & & & 1.77 & & & & 2.99 & & & & 1.73 & \\
\hline $\mathrm{Pb} \times \mathrm{N}$ & & & 2.69 & & & & 3.53 & & & & 5.97 & & & & 3.45 & \\
\hline
\end{tabular}

As can be seen in Fig. 3, the amount of $\mathrm{NO}_{3}-\mathrm{N}$ content in soil at $60 \%$ WHC was gradually increased with the progress of the incubation period irrespective of treatments and decreased significantly with the successive addition of $\mathrm{Pb}$ throughout the incubation period. The percent increase from 7 to 28 days of incubation was 48.6, 48.2, 57.8, and $51.4 \%$ at $0,10,20$, and $50 \mathrm{mg} \mathrm{kg}^{-1} \mathrm{~Pb}$, respectively. The mean effect of urea application (Fig. 4) on $\mathrm{NO}_{3}-\mathrm{N}$ content showed that the amount of $\mathrm{NO}_{3}-\mathrm{N}$ content gradually increased with the incubation time. The percent increase from 7 to 28 days of incubation was 36.54, $60.35,63.68$, and $39.34 \%$ at $0,50,100$, and $200 \mathrm{mg} \mathrm{kg}^{-1} \mathrm{~N}$, respectively.

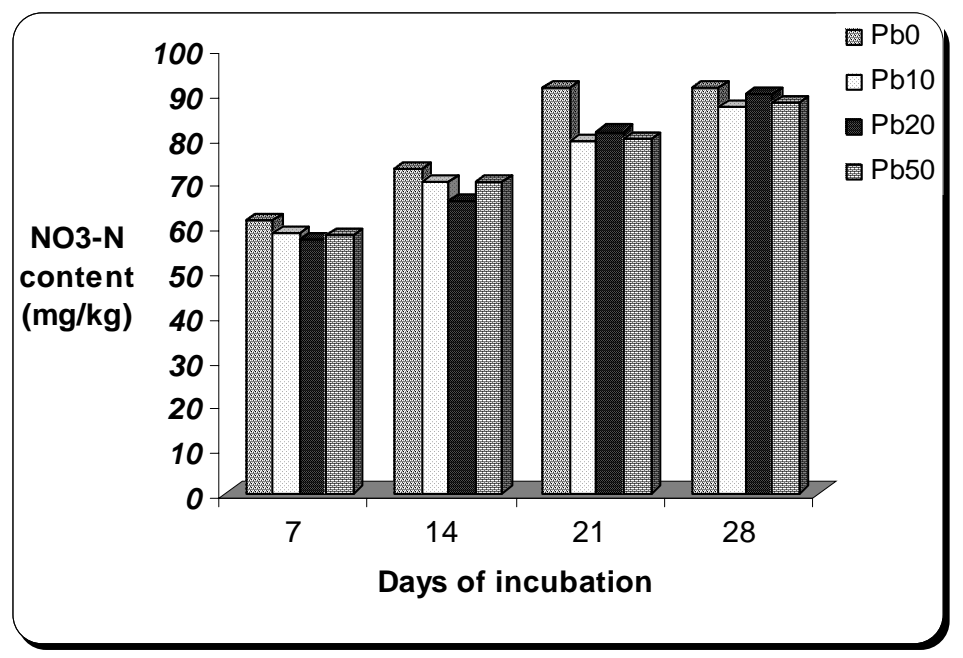

FIGURE 3. Mean effect of different levels of $\mathrm{Pb}$ on the changes in $\mathrm{NO}_{3}-\mathrm{N}$ content in soil under 60\% WHC.

\section{Transformation of $\mathrm{NH}_{4}-\mathrm{N}$ at Saturated Moisture Condition}

The amount of $\mathrm{NH}_{4}-\mathrm{N}$ content gradually increased with the progress of the incubation period, irrespective of $\mathrm{Pb}$ and urea applied (Table 4). The magnitude of such an increase varied with the treatments, recording a significant increase with the application of $\mathrm{N}$ at $200 \mathrm{mg} \mathrm{kg}^{-1}$ over that of the control. However, such an increase in $\mathrm{NH}_{4}-\mathrm{N}$ content in soil at saturated condition decreased with the application of $\mathrm{Pb}$ at different 


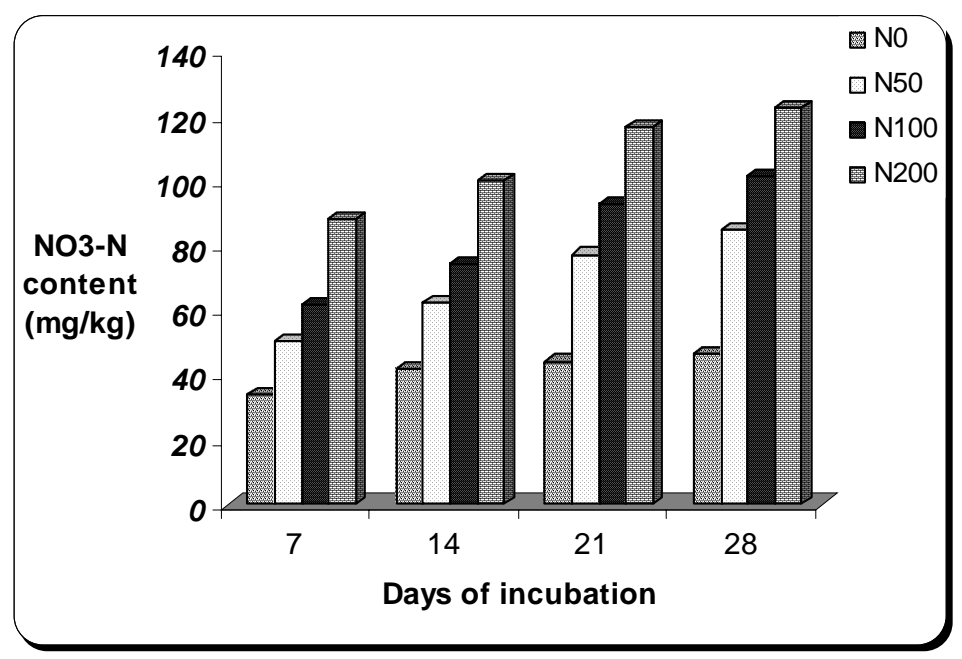

FIGURE 4. Mean effect of different levels of $\mathrm{N}$ on the changes in $\mathrm{NO}_{3}-\mathrm{N}$ content in soil under 60\% WHC.

TABLE 4

Effect of Different Levels of $\mathrm{Pb}$ and $\mathrm{N}$ on the Changes in $\mathrm{NH}_{4}-\mathrm{N}\left(\mathrm{mg} \mathrm{kg}^{-1}\right)$ Content in Soil under Saturated Condition

\begin{tabular}{|c|c|c|c|c|c|c|c|c|c|c|c|c|c|c|c|c|}
\hline \multirow{3}{*}{$\begin{array}{l}\text { Treat- } \\
\text { ments }\end{array}$} & \multicolumn{16}{|c|}{ Period of Incubation (Days) } \\
\hline & \multicolumn{4}{|c|}{7} & \multicolumn{4}{|c|}{14} & \multicolumn{4}{|c|}{21} & \multicolumn{4}{|c|}{28} \\
\hline & $\mathbf{N}_{0}$ & $\mathbf{N}_{50}$ & $\mathbf{N}_{100}$ & $\mathbf{N}_{200}$ & $\mathbf{N}_{0}$ & $\mathbf{N}_{50}$ & $\mathbf{N}_{100}$ & $\mathbf{N}_{200}$ & $\mathrm{~N}_{0}$ & $\mathbf{N}_{50}$ & $\mathbf{N}_{100}$ & $\mathbf{N}_{200}$ & $\mathbf{N}_{0}$ & $\mathbf{N}_{50}$ & $\mathbf{N}_{100}$ & $\mathbf{N}_{200}$ \\
\hline $\mathrm{Pb}_{0}$ & 31.7 & 45.6 & 58.5 & 85.3 & 32.6 & 47.3 & 59.5 & 86.7 & 36.0 & 59.5 & 68.5 & 98.6 & 41.9 & 64.2 & 76.2 & 110.4 \\
\hline $\mathrm{Pb}_{10}$ & 30.0 & 43.4 & 60.2 & 83.6 & 32.4 & 49.8 & 67.2 & 99.9 & 43.6 & 60.6 & 72.2 & 106.2 & 50.1 & 72.2 & 79.8 & 118.0 \\
\hline $\mathrm{Pb}_{20}$ & 29.8 & 44.1 & 58.1 & 81.4 & 31.4 & 50.7 & 65.1 & 106 & 42.7 & 60.6 & 76.4 & 117.0 & 60.2 & 67.4 & 90.3 & 124.0 \\
\hline $\mathrm{Pb}_{50}$ & 29.4 & 49.7 & 58.6 & 79.8 & 30.3 & 56.7 & 70.0 & 93.0 & 41.8 & 69.1 & 81.1 & 107.0 & 28.7 & 76.8 & 85.0 & 122.0 \\
\hline \multicolumn{17}{|l|}{$\begin{array}{c}\operatorname{LSD}(p= \\
0.05)\end{array}$} \\
\hline $\mathrm{Pb}$ & & & 2.73 & & & & 1.03 & & & & 1.94 & & & & 1.47 & \\
\hline $\mathrm{N}$ & & & 2.73 & & & & 1.03 & & & & 1.94 & & & & 1.47 & \\
\hline $\mathrm{Pb} \times \mathrm{N}$ & & & 5.46 & & & & 2.06 & & & & 3.89 & & & & 2.94 & \\
\hline
\end{tabular}

levels. The application of $\mathrm{Pb}$ in saturated soil might have some effect on the retardation of urea hydrolysis. The result of the present investigation was in agreement with the findings of Antil et al.[7] who revealed that the microbial biomass and urease activity declined with increasing levels of $\mathrm{Pb}$ in the soil. Urea hydrolysis was faster in uncontaminated soils (97.2\% within $24 \mathrm{~h}$ ) compared to contaminated soil $(91.1 \%$ within $24 \mathrm{~h})$. They also observed that the maximum accumulation of $\mathrm{NH}_{4}-\mathrm{N}$ was found between 7 and 14 days in the soils containing 496.4 and $589.9 \mathrm{mg} \mathrm{kg}^{-1} \mathrm{~Pb}$, respectively.

Pal and Chhonkar[16] reported that the reduction of the urea hydrolysis rate may be ascribed to the activation of urea molecules by sodium and hydroxyl ions. The results also showed that the higher $\mathrm{NH}_{4}-\mathrm{N}$ concentration was recovered in Pb-treated soils, as $\mathrm{Pb}$ likely caused $\mathrm{NH}_{4}-\mathrm{N}$ persistence in the soil by restricting the activity of nitrobacters and a higher amount of $\mathrm{NH}_{4}-\mathrm{N}$ was recorded with higher levels of $\mathrm{Pb}$ [13]. The persistence of a greater amount of $\mathrm{NH}_{4}-\mathrm{N}$ content at the later period of incubation might be due to the very slower rate of urea hydrolysis under saturated soil moisture content, with higher levels of $\mathrm{Pb}$ and $\mathrm{N}$ application. 
Fig. 5 illustrates that the mean effect of $\mathrm{Pb}$ did not show significant difference on $\mathrm{NH}_{4}-\mathrm{N}$ content among different levels of $\mathrm{Pb}$ within the incubation period and higher $\mathrm{NH}_{4}-\mathrm{N}$ content was recovered in $\mathrm{Pb}$ treated soils throughout the incubation period. The maximum $\mathrm{NH}_{4}-\mathrm{N}$ content was found when $\mathrm{Pb}$ was applied at 20 and $50 \mathrm{mg} \mathrm{kg}^{-1}$ at later stages of incubation, as it tried to make $\mathrm{NH}_{4}-\mathrm{N}$ persist, probably by restricting the activity of nitrobacters with higher levels of $\mathrm{Pb}$. This is also supported by Gupta and Chaudhry[10] who reported that a higher concentration of $\mathrm{Pb}$ at $400 \mathrm{mg} \mathrm{kg}^{-1}$ delayed the nitrification and $\mathrm{NH}_{4}-\mathrm{N}$ persisted in the soil for a longer period. Fig. 6 summarizes the mean effect of urea application on the changes in $\mathrm{NH}_{4}-\mathrm{N}$ content under saturated soil condition. The $\mathrm{NH}_{4}-\mathrm{N}$ content increased significantly with higher levels of $\mathrm{N}$ and gradually increased with the progress of incubation time. The percent increase from 7 to 28 days of incubation was 74.45, 53.50, 40.73, and $43.72 \%$ at $0,50,100$, and $200 \mathrm{mg} \mathrm{kg}^{-1} \mathrm{~N}$, respectively (Fig. 6).

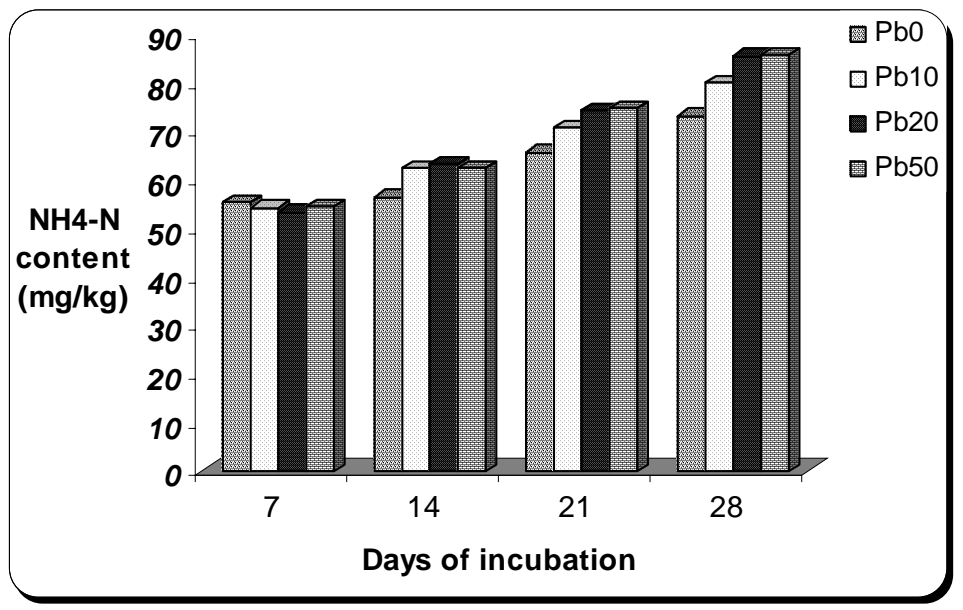

FIGURE 5. Mean effect of different levels of $\mathrm{Pb}$ on the changes in $\mathrm{NH}_{4}-\mathrm{N}$ content under saturated soil.

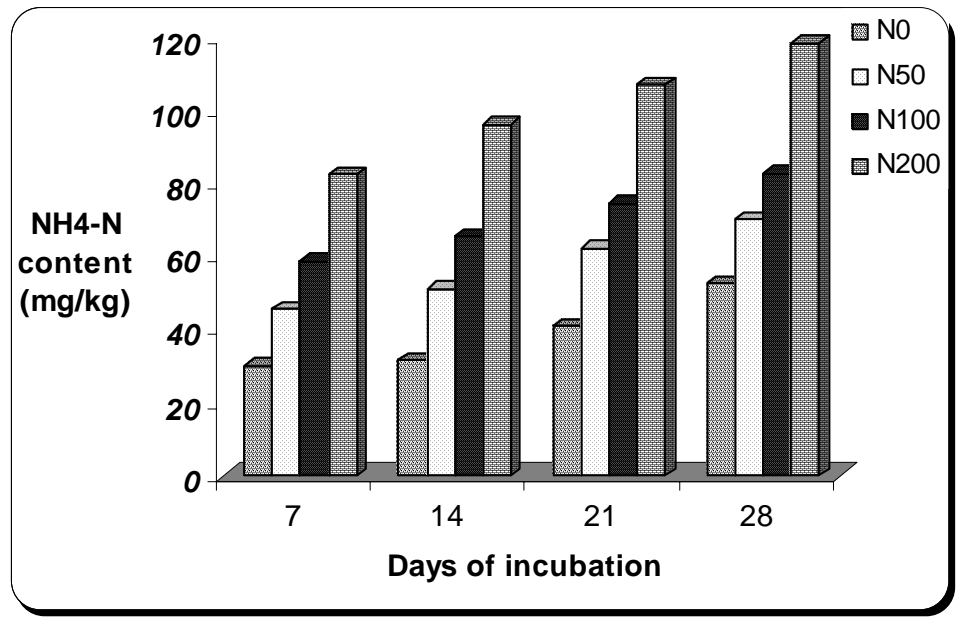

FIGURE 6. Mean effect of different levels of $\mathrm{N}$ on the changes in $\mathrm{NH}_{4}-\mathrm{N}$ content under saturated soil. 


\section{Transformation of $\mathrm{NO}_{3}-\mathrm{N}$ at Saturated Moisture Condition}

The changes in $\mathrm{NO}_{3}-\mathrm{N}$ content in saturated soil gradually decreased with time, irrespective of the treatment (Table 5). The lowest $\mathrm{NO}_{3}-\mathrm{N}$ content was recorded in control treatment. The application of urea, however, increased the amount of $\mathrm{NO}_{3}-\mathrm{N}$ content in the soil initially and, thereafter, the amount of the same decreased at the later period of incubation. Such magnitude of variation has been found to be counteracted either by the sole application of $\mathrm{Pb}$ or the combined application of $\mathrm{Pb}$ and $\mathrm{N}$ at their various levels. Considering the interaction, it was observed that the amount of $\mathrm{NO}_{3}-\mathrm{N}$ content significantly decreased in $\mathrm{Pb}_{50} \mathrm{~N}_{0}$ treatment, which was closely followed by $\mathrm{Pb}_{10} \mathrm{~N}_{0}$ and $\mathrm{Pb}_{20} \mathrm{~N}_{0}$ treatments, suggesting an antagonistic effect between $\mathrm{Pb}$ and $\mathrm{N}$ in relation to changes in $\mathrm{NO}_{3}-\mathrm{N}$ content in soils.

The amount of $\mathrm{NO}_{3}-\mathrm{N}$ in saturated soil has always been found to be lower than $\mathrm{NH}_{4}-\mathrm{N}$. Such a decrease, however, was further enhanced with the application of $\mathrm{Pb}$. Such a decrease might be due to the very slow rate of urease activity, as well as nitrification. Gupta and Chaudhry[13] reported that heavy metal decreases the rate of hydrolysis particularly at the high level of $400 \mathrm{mg} \mathrm{kg}^{-1}$. The retardation was in the order of $\mathrm{Hg}>\mathrm{Zn}>\mathrm{Ni}>\mathrm{Pb}$. Urease activity is sensitive to different heavy metals as urease-SH groups react with metallic cations at higher concentrations.

TABLE 5

Effect of Different Levels of $\mathrm{Pb}$ and $\mathrm{N}$ on the Changes in $\mathrm{NO}_{3}-\mathrm{N}\left(\mathrm{mg} \mathrm{kg}^{-1}\right)$ Content in Soil under Saturated Condition

\begin{tabular}{|c|c|c|c|c|c|c|c|c|c|c|c|c|c|c|c|c|}
\hline \multirow{3}{*}{$\begin{array}{l}\text { Treat- } \\
\text { ments }\end{array}$} & \multicolumn{16}{|c|}{ Period of Incubation (Days) } \\
\hline & \multicolumn{4}{|c|}{7} & \multicolumn{4}{|c|}{14} & \multicolumn{4}{|c|}{21} & \multicolumn{4}{|c|}{28} \\
\hline & $\mathrm{N}_{0}$ & $\mathbf{N}_{50}$ & $\mathbf{N}_{100}$ & $\mathbf{N}_{200}$ & $\mathbf{N}_{0}$ & $\mathbf{N}_{50}$ & $\mathbf{N}_{100}$ & $\mathbf{N}_{200}$ & $\mathbf{N}_{0}$ & $\mathbf{N}_{50}$ & $\mathbf{N}_{100}$ & $\mathbf{N}_{200}$ & $\mathbf{N}_{0}$ & $\mathbf{N}_{50}$ & $\mathbf{N}_{100}$ & $\mathbf{N}_{200}$ \\
\hline $\mathrm{Pb}_{0}$ & 24.2 & 35.9 & 46.5 & 70.9 & 22.8 & 32.1 & 43.2 & 58.6 & 18.6 & 26.8 & 34.6 & 43.7 & 12.1 & 17.2 & 24.4 & 30.9 \\
\hline $\mathrm{Pb}_{10}$ & 23.8 & 35.8 & 47.6 & 71.1 & 21.6 & 30.0 & 40.8 & 56.3 & 15.8 & 24.6 & 30.7 & 41.2 & 11.7 & 15.6 & 19.3 & 26.7 \\
\hline $\mathrm{Pb}_{20}$ & 23.3 & 36.1 & 47.0 & 68.0 & 21.2 & 28.9 & 42.6 & 50.0 & 15.4 & 23.6 & 30.4 & 36.9 & 11.5 & 17.9 & 21.2 & 23.4 \\
\hline $\mathrm{Pb}_{50}$ & 22.7 & 35.3 & 46.0 & 68.4 & 18.7 & 26.6 & 35.3 & 54.2 & 14.7 & 21.4 & 25.6 & 41.6 & 11.2 & 17.6 & 19.7 & 28.4 \\
\hline \multicolumn{17}{|l|}{$\begin{array}{l}\operatorname{LSD}(p= \\
0.05)\end{array}$} \\
\hline $\mathrm{Pb}$ & & & 1.97 & & & & 1.18 & & & & 1.60 & & & & 2.55 & \\
\hline$N$ & & & 1.97 & & & & 1.18 & & & & 1.60 & & & & 2.55 & \\
\hline $\mathrm{Pb} \times \mathrm{N}$ & & & 3.95 & & & & 2.36 & & & & 3.20 & & & & 5.10 & \\
\hline
\end{tabular}

The research results also pointed out that the amount of $\mathrm{NO}_{3}-\mathrm{N}$ content was lower in Pb-treated soil compared to control, which suggests that the rate of nitrification under saturated condition is slower in the presence of $\mathrm{Pb}$, which also inhibits the urease activity[17]. Gupta and Chaudhry[13] also reported that the concentration of $\mathrm{NO}_{3}-\mathrm{N}$ content in the control treatment was significantly higher than in the metal-treated soil. They also reported that increasing levels of $\mathrm{Pb}, \mathrm{Ni}, \mathrm{Hg}$, and $\mathrm{Zn}$ from 200 to $400 \mathrm{mg} \mathrm{kg}^{-1}$ soil $\mathrm{NO}_{3}-\mathrm{N}$ content significantly decreased, which is in line with the results of our investigation.

As can be seen in Fig. 7, $\mathrm{NO}_{3}-\mathrm{N}$ content significantly decreased with the increase of $\mathrm{Pb}$ concentrations ( $\left.0-50 \mathrm{mg} \mathrm{kg}^{-1}\right)$. The maximum $\mathrm{NO}_{3}-\mathrm{N}$ content was recorded at 7 days after incubation and gradually decreased with the progress of incubation. The percent decrease from 7 to 28 days after incubation was 52.1, 58.9, 57.5, and $55.4 \%$ at $0,10,20$, and $50 \mathrm{mg} \mathrm{kg}^{-1} \mathrm{~Pb}$, respectively. Fig. 8 represents the mean effect of urea application on the changes in $\mathrm{NO}_{3}-\mathrm{N}$ content at saturated condition. The $\mathrm{NO}_{3}-\mathrm{N}$ content significantly increased with higher levels of $\mathrm{N}$ and the $\mathrm{NO}_{3}-\mathrm{N}$ content gradually decreased with the progress of the incubation period. The percent decrease in $\mathrm{NO}_{3}-\mathrm{N}$ content from 7 to 28 days after incubation was 50.55, 52.3, 54.77, and $60.7 \%$ at $0,50,100$, and $200 \mathrm{mg} \mathrm{kg}^{-1} \mathrm{~N}$, respectively. 


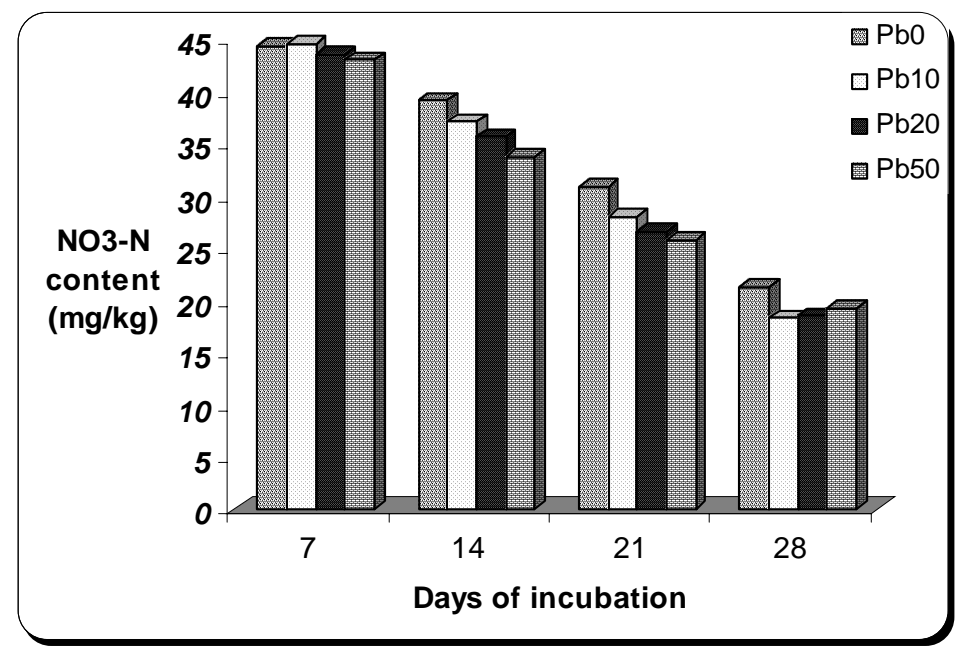

FIGURE 7. Mean effect of different levels of $\mathrm{Pb}$ on the changes in $\mathrm{NO}_{3}-\mathrm{N}$ content under saturated soil.

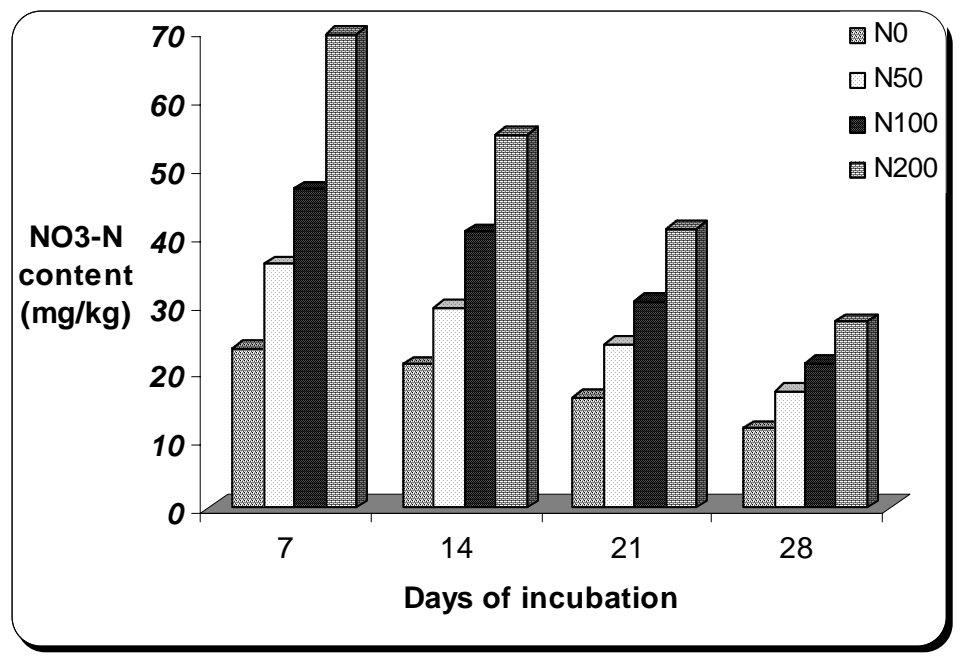

FIGURE 8. Mean effect of different levels of $\mathrm{N}$ on the changes in $\mathrm{NO}_{3}-\mathrm{N}$ content under saturated soil.

\section{CONCLUSIONS}

The present experimental results confirmed that the amount of $\mathrm{NO}_{3}-\mathrm{N}$ at $60 \%$ WHC was always higher as compared to $\mathrm{NH}_{4}-\mathrm{N}$ content, suggesting a higher rate of nitrification prevailing at $60 \%$ WHC than at saturated condition. Increasing the level of $\mathrm{Pb}$ decreases the $\mathrm{NO}_{3}-\mathrm{N}$ and increases the $\mathrm{NH}_{4}-\mathrm{N}$ content, which might be due to the moderation of ammonification-nitrification processes. The result suggested the existence of an antagonism effect between $\mathrm{Pb}$ and $\mathrm{N}$ in relation to changes in $\mathrm{NO}_{3}-\mathrm{N}$ content in the soil.

\section{REFERENCES}

1. Gupta, A.P., Narwal, R.P., and Poonia, S.R. (1993) Proc. Indo-German Conf. Impact and Management of Modern Agric. on Environ., Haryana Agricultural University, Hisar, India. 36. 
2. Soderstrom, B., Baath, E., and Lundgeron, B. (1983) Decrease in soil microbial activity and biomasses owing to nitrogen amendments. Can. J. Microbiol. 29, 1500-1506.

3. Khonje, D.J., Varsa, E.C., and Klubek, B. (1989) The acidulation effects of nitrogenous fertilizers on selected chemical and microbiological properties of soil. Commun. Soil Sci. Plant Anal. 20, 1377-1395.

4. Sarathchandra, S.U., Perrot, K.W., and Littler, R.A. (1989) Soil microbial biomass: influence of simulated temperature changes on the size, activity and nutrient content. Soil Biol. Biochem. 21, 987-993.

5. $\quad$ Bremner, J.M. and Mulvaney, R.L. (1978) In Soil Enzymes. Burns, R.G., Ed. Academic Press, London. pp. 51-96.

6. Yadav, D.S., Kumar, V., Singh, M., and Relan, P.S. (1987) Effect of temperature and moisture on kinetics of urea hydrolysis and nitrification. Aust. J. Soil Res. 25, 185-191.

7. Antil, R.S., Mahata, M.K., and Narwal, R.P. (2006) Urea hydrolysis and nitrogen transformation in soils containing different lead contents. Arch. Agron. Soil Sci. 52, 69-77.

8. Lindsay, W.L. and Norvell, W.A. (1978) Development of DTPA soil test for zinc, iron, manganese and copper. Soil Sci. Soc. Am. J. 42, 421-428.

9. Sahrawat, K.L. and Burford, J.R. (1982) Modification of the alkaline permanganate method for assessing the availability of soil nitrogen in upland soils. Soil Sci. 133, 53-57.

10. Gupta, S.K. and Chaudhry, M.L. (2002) Influence of heavy metals on urea transformation in a saline soil. J. Indian Soc. Soil Sci. 50, 158-163.

11. Nitant, H.C. (1974) Urea transformation in salt affected and normal soils. J. Indian Soc. Soil Sci. 22, $234-239$.

12. Sindhu, M.A. and Cornfield, A.M. (1967) Effect of lead chloride and moisture content on ammonification and nitrification in incubated soil. J. Sci. Fd. Agric. 18, 505.

13. Gupta, S.K. and Chaudhry, M.L. (1994) Influence of heavy metals and temperature on urea transformation in a typic ustochrept. J. Indian Soc. Soil Sci. 42, 203-208.

14. Barnhart, C.L. and Vestal, R. (1983) Effect of environmental toxicant on metabolic activity of natural microbial communities. Appl. Environ. Microbiol. 46, 970-977.

15. Capone, D.G., Reese, D., and Kiene, R.P. (1983) Effects of metals on methanogenesis, sulfate reduction, carbon dioxide evolution, and microbial biomass in anoxic salt marsh sediments. Appl. Environ. Microbiol. 45, $1586-1591$.

16. Pal, S. and Chhonkar, P.K. (1979) Thermal sensitivity and kinetic properties of soil urease. J. Indian Soc. Soil Sci. 27, 43-47.

17. Tabatabai, M.A. (1977) Effects of trace elements on urease activity in soils. Soil Biol. Biochem. 9, 9-13.

\section{This article should be cited as follows:}

Das, D.K., Bashetti, P., Naik, S.K., and Sur, P. (2007 Effect of lead on the transformation of urea-N in fly ash-contaminated soils under different moisture regimes. TheScientificWorldJOURNAL 7, xxx-xxx. DOI 10.1100/tsw.2007.129. 


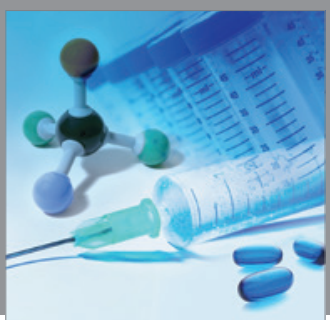

International Journal of

Medicinal Chemistry

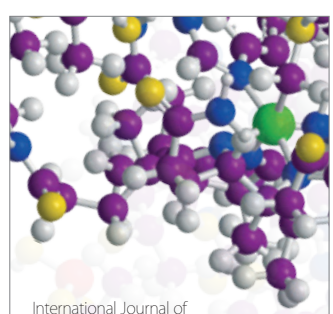

Carbohydrate Chemistry

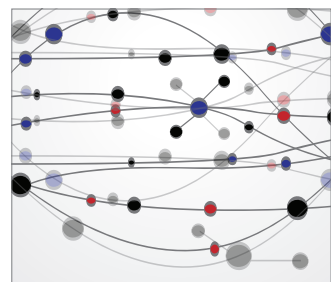

The Scientific World Journal
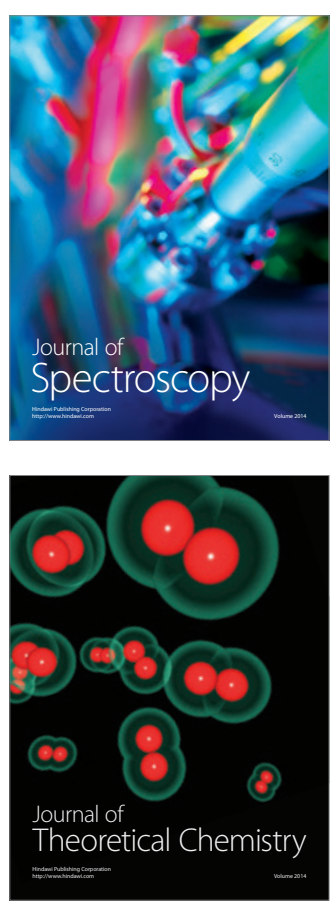
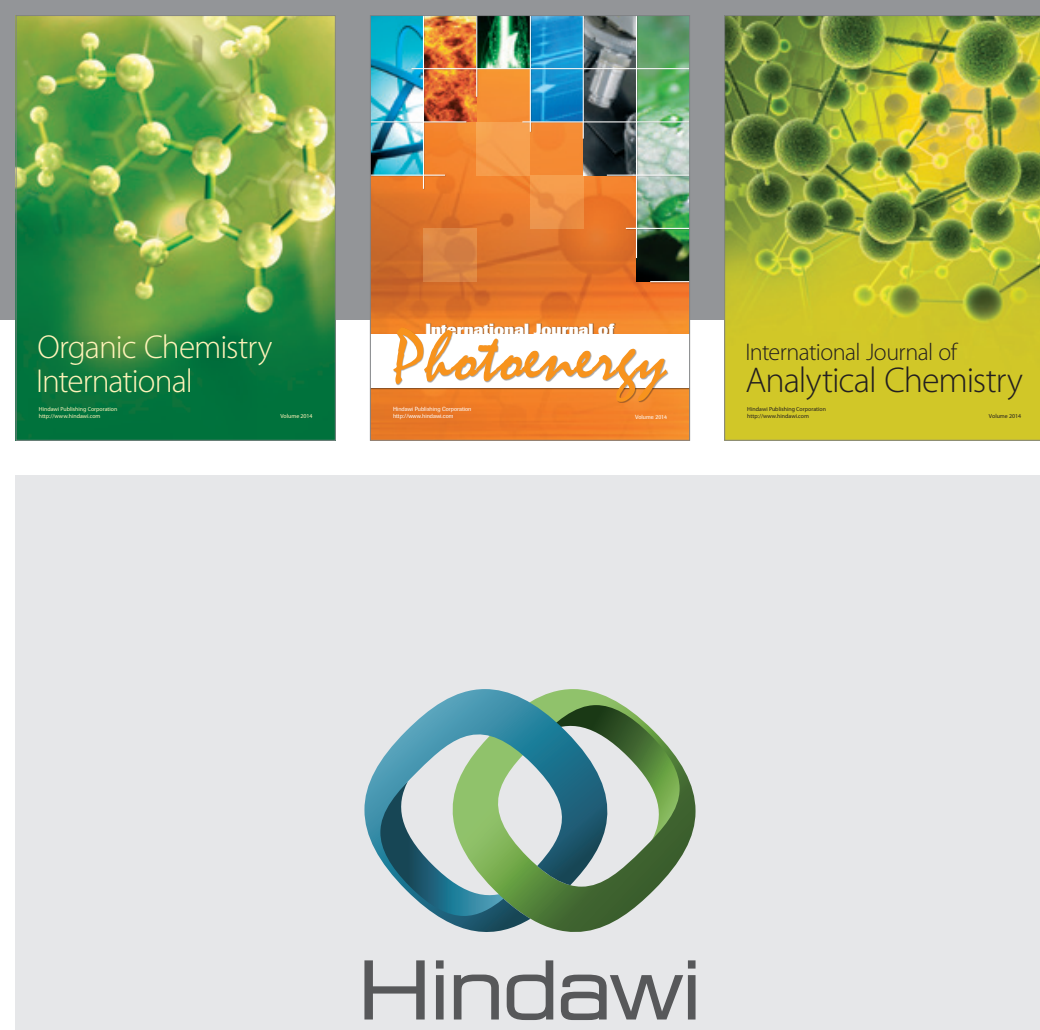

Submit your manuscripts at

http://www.hindawi.com
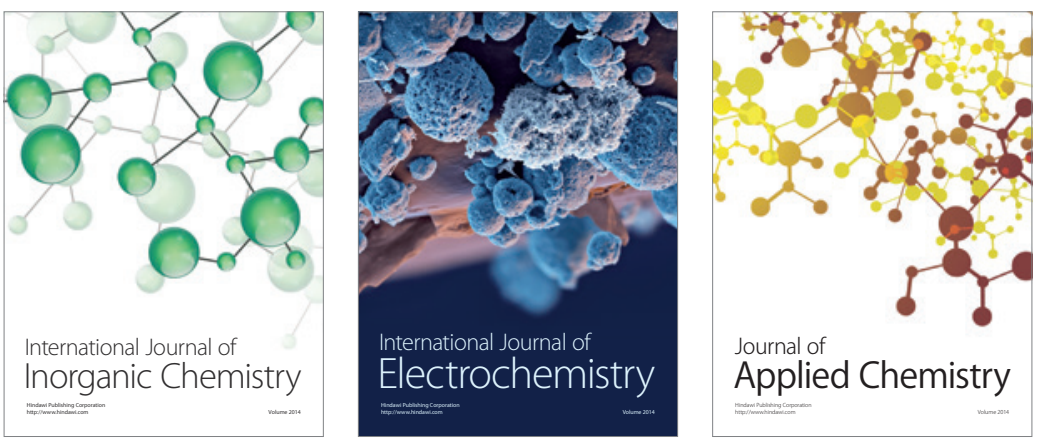

Journal of

Applied Chemistry
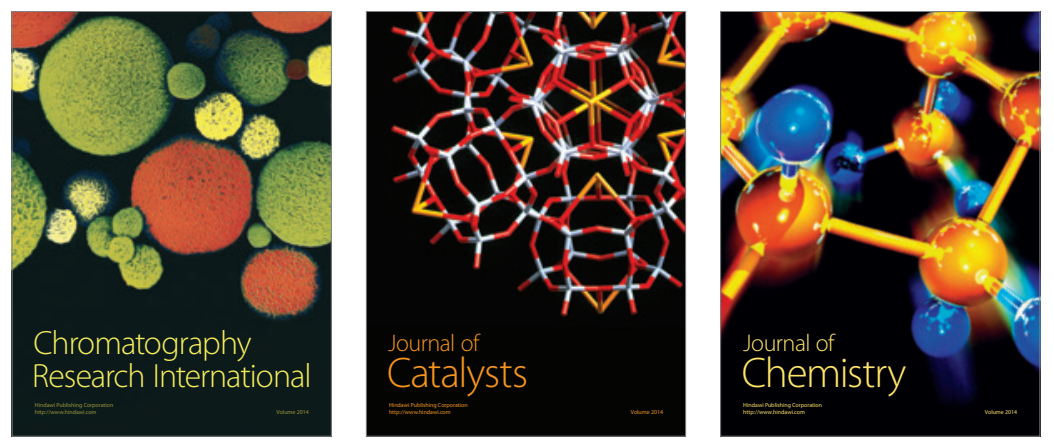
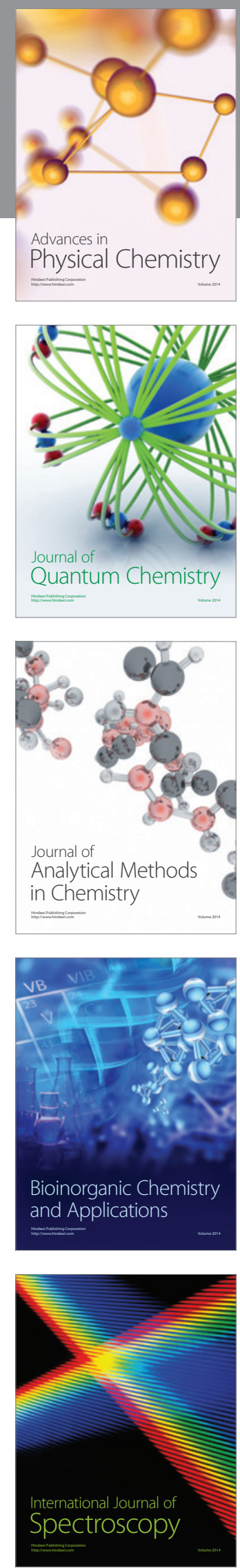